\title{
Этнопоэтический подход к изучению современной литературы Саяно-Алтая (на материале тувинской и хакасской поэзии)
}

\author{
Наталья Л. Кольчикова, Валерий П. Прищепа \\ Хакасский государственный университет им. Н. Ф. Катанова, Российская Федерация
}

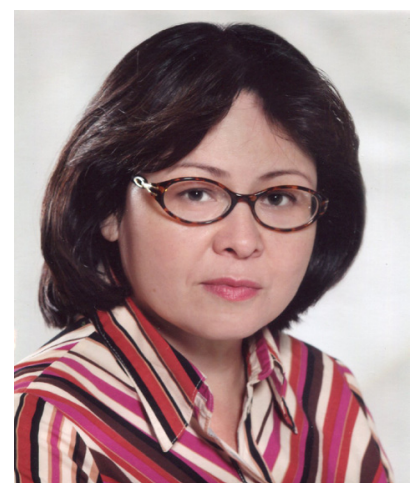

В статье представлены результаты изучения современной литературы двух регионов территории Саяно-Алтая - тувинской и хакасской - на основе этнопоэтического подхода для выявления этнопоэтических констант. В поэзии такие константы рассматриваются как образы-символы, стилистические формулы (В. Н. Захаров, В. М. Гацак и др.). Источниковой базой для анализа стали «прецедентные» тексты современной тувинской и хакасской поэзии и их переводы на русский язык, взятые из сборников отдельных тувинских авторов: М. Б. Кенин-Лопсана, А. А. Даржая, Н. Ш. Куулара. Для исследования творчества хакасских авторов нами были использованы сборники стихов В. Г. Майнашева, изданные на хакасском и русском языках (в переводе автора); Н. М. Ахпашевой, С. А. Майнагашева (Сибдей Том).

В произведениях тувинских поэтов выделены этнопоэтические константы, которые репрезентируют тувинскую картину мира (небо, мать-земля, степи, горы, реки) и индивидуально-авторские образы-символы (материнская (отцовская, дедовская) юрта, артыш, зеленый чай, сизый дым, очаг, дверь и порог юрты, опорный шест Багана, звезды и др.). Ухакасских поэтов также выделены традиционные этнопоэтические константы (солнца, неба, степи, горы, курганов, коня, волка и др.) и индивидуально авторские образы-символы (богородская трава, жарки, ковыль, герои-алыпы, Салбык, шаман, бубен, Запад-Восток, Европа-Азия и т. д.).

Исследование подчеркивает генетическое родство обеих литератур, основанное на родственности культур. Каждый из рассмотренных авторов является национальным поэтом, вскрывающим мировоззренческие и эстетические богатства своего народа.

Ключевые слова: этнопоэтика; сравнительное литературоведение; национальная культура; этнопоэтическая константа; тувинская поэзия; хакасская поэзия; тувинская литература; хакасская литература; тувинская культура; хакасская культура; образ-символ

Кольчикова Н. Л., Прищепа В. П. Этнопоэтический подход к изучению современной литературы Саяно-Алтая (на материале тувинской и хакасской поэзии) // Новые исследования Тувы. 2020, № 3. C. 210-227. DOI: www.doi. org/10.25178/nit.2020.3.15

Кольчикова Наталья Лаврентьевна - кандидат педагогических наук, доцент кафедры русского языка и литературы Хакасского государственного университета им. Н. Ф. Катанова. Адрес: 655017, Россия, г. Абакан, ул. Ленина, д. 92. Тел.: +7 (913) 542-26-05. Эл. адрес: pollik21@mail.ru

Прищепа Валерий Павлович - доктор филологических наук, профессор кафедры русского языка и литературы Хакасского государственного университета им. Н. Ф. Катанова. Адрес: 665017, Россия, г. Абакан, ул. Ленина, д. 92. Тел.: +7 (983) $447-66-21$. Эл. адрес: pvp-1957@mail.ru

KOLCHIKOVA, Natalya Lavrentyevna, Candidate of Pedagogy, Associated professor, Department of Russian Language and Literature, N.F. Katanov Khakas State University. Postal address: 92 Lenin St., 665017 Abakan, Russia. Tel.: +7 (913) 542-26-05. E-mail: pollik21@mail.ru ORCID ID: 0000-0002-0547-0592

PRISHCHEPA, Valery Pavlovich, Doctor of Philology, Professor, Department of Russian Philology, N. F. Katanov Khakas State University. Postal address: 92 Lenin St., 665017 Abakan, Russia. Tel.: +7 (983) 447-66-21. E-mail: pvp-1957@mail.ru ORCID ID: 0000-0002-3913-2022 


\title{
An ethnopoetic approach to the study of modern Sayan-Altai literature: the cases of Tuvan and Khakas poetry
}

\author{
Natalia L. Kolchikova, Valerii P. Prishchepa \\ N. F. Katanov Khakas State University, Russian Federation
}

\begin{abstract}
The article presents the outcomes of a study of the modern literature of two Sayan-Altai regions - Tuva and Khakassia, making use of an ethnopoetic approach to discover underlying ethnopoetic constants. In poetry, these constants are presented as symbolic images and stylistic formulae (according to V. N. Zakharov, V. M. Gatsak etc.) Our analysis is based on 'precedent' texts of modern Tuvan and Khakas poetry and its translations into Russian, taken from the selected collections of Tuvan authors: M. B. Kenin-Lopsan, A. A. Darzhai, and N. Sh. Kuular. Of Khakas writers, we relied on collections of poems by V. G. Mainashev, published in Khakas and Russian (translated by the author); N. M. Akhpasheva, and S. A. Mainagashev (Sibdey Tom).

Ethnopoetic constants found typical for Tuvan world view include the sky, Mother Earth, steppes, mountains, rivers. These are accompanied by symbols advanced by individual authors, such as the ancestral (mother's, father's, or grandfather's) yurt, artysh, green tea, bluish smoke, hearth, door and doorstep of the yurt, support pole of Bagan, or stars. Khakas poets also make use of similar ethnopoetic constants (the sun, the sky, steppes, mountains, the horse, the wolf etc.) and authorial symbolic images (the wild thyme, globe flower, needle grass, alyp heroes, Salbyk, shaman, the tambourine, East-West, Europe-Asia etc.)

Our study points out the genetic affinity between both literatures based on the affinity of the respective cultures. Each of the considered authors is a national poet who reveals the ideological and aesthetic riches of their people.
\end{abstract}

Keywords: ethnopoetics; comparative literature; national culture; ethnopoetic constant; Tuvan poetry; Khakas poetry; Tuvan literature; Khakas literature; Tuvan culture; Khakas culture; symbolic image

\section{For citation:}

Kolchikova N. L. and Prishchepa V. P. Etnopoeticheskii podkhod k izucheniiu sovremennoi literatury Saiano-Altaia (na materiale tuvinskoi i khakasskoi poezii) [An ethnopoetic approach to the study of modern Sayan-Altai literature: the cases of Tuvan and Khakas poetry]. New Research of Tuva, 2020, no. 3, pp. 210-227. (In Russ.). DOI: www.doi.org/10.25178/ nit.2020.3.15

\section{Введение}

В современном литературоведении среди факторов, обусловливающих сплочение определенных литератур в региональное целое, весомым является фактор культурной общности, восприятия определенных ценностных установок. Этнопоэтический подход исследует связь литературы с фольклором, национальным художественным мировидением, этнологическими и этнографическими традициями, национальным языком и стилевыми формами как синтез культуры этноса.

Литературы Саяно-Алтайского региона представляют собой единую историческую, этнокультурную общность. В современном литературоведении понятие региона употребляется в нескольких значениях: регионально-языковом, регионально-культурном, регионально-эстетическом. На этой основе литературы Саяно-Алтайского региона объединяются в единую общность - алтайская, тувинская, хакасская, шорская (Бикмухаметов, 1983: 134).

Известный ученый, одним из первых исследовавший общность национальных литератур Сибири, С. Ж. Балданов отмечал, что у сибирских, в том числе тувинских, хакасских литератур «художественное мышление развивалось под воздействием богатейшего фольклора... Сходство наблюдается в том, что в фольклоре народов Сибири всегда дается целый сонм образов из мира природы, из космических и земных явлений, сходство видится в композиционных приемах, в самой концепции, в характере исполнения и в целом во всей структуре произведений» (Балданов, 1983: 147). 
О важности сопоставительного исследования национальных литератур Сибири на современном этапе в аспекте мифофольклорного компонента в них для выявления общих свойств писали С. Ж. Балданов (Балданов, 2005), А. Л. Кошелева (Кошелева, 2015), Н. С. Майнагашева (Майнагашева, 2008), Л. В. Челтыгмашева (Челтыгмашева, 2009). Тувинскую и хакасскую литературы связывают не только историческое прошлое, но и языковое родство, а также, при всем многообразии стилеобразующих факторов, преемственная связь с традиционными формами фольклорного художественного мышления, эстетическая природа которого определяется спецификой национального самосознания и мироощущения. Общность обеих литератур обусловлена наличием близких сюжетов, тем, мотивов, этнопоэтических констант.

Элементы фольклорного стиля, входя в новую эстетическую реальность, складывающуюся в творчестве художника, вступают во взаимодействие с опытом писателя, его духовным миром и представляют духовный мир своего народа и особенности его мировосприятия в эстетически подвижных образных формах. Тем самым открываются новые художественные возможности использования фольклорных традиций, новые стилевые перспективы их взаимодействия с литературно-письменными жанрами.

Цель данной статьи заключается в изучении литератур двух регионов территории Саяно-Алтая тувинской и хакасской на основе этнопоэтического подхода для выявления этнопоэтических констант, которые являются органичными художественной культуре каждого народа, для раскрытия их своеобразных, неповторимых черт. Этнопоэтические константы, по мнению В. Н. Захарова, это закрепленные в образно-символической сфере языка единицы, которые формируют национальную картину мира (Захаров, 1998: 9). В поэтическом творчестве константами, в наибольшей степени содержащими этнокультурную составляющую, связанными с культурной традицией, являются образысимволы, стилистические формулы (Алефиренко и др., 2012: 26).

Термин «этнопоэтика» первыми стали использовать зарубежные исследователи. Так, Д. Ротенберг считал, что обращение к наследию традиционных культур способствует расширению изобразительных возможностей языка (Rotenberg, 1983: 50). Еще один исследователь Г. Джэйсон пишет о том, что этнопоэтика является той частью поэтики, которая в большей степени сориентирована на лингвистику; она изучает художественные свойства устной и народной литературы, а также мифический аспект данных произведений (Jason, 2000: 273). Одним из первых данный подход к изучению региональных литератур Сибири применил уже упомянутый бурятский ученый С. Ж. Балданов. Данный исследователь, рассматривая сибирские национальные литературы в контексте общероссийского литературного процесса, указал на их «идейное единство, единство метода и художественно-эстетических принципов, единство целей, стилей, проблематики, художественных исканий, единство нравственно-эстетических и этнических идеалов, единство типических характеров и типических обстоятельств, все более углубляющееся интернациональное единство с точки зрения многонационального состава литературы» (Балданов, 2005: 5).

Современное литературоведение изучает разные аспекты данного подхода: этноконфессиональный - В. Н. Захаров (Захаров, 1998), В. Н. Зырянов (Зырянов, 2018) и др.; фольклорно-мифологический - У. Б. Далгат (Далгат, 2004), О. К. Лагунова (Лагунова, 2008), А. Е. Чернова (Чернова, 2013); этимологический: В. А. Маслова (Маслова, 2016), 3. П. Табакова (Табакова, 2014) и др. В тувинском и хакасском литературоведении такой подход отчасти реализуется в работах У. Донгак (Донгак, 2013), Д. С. Куулара (Куулар, 2002), Л. С. Мижит (Мижит, 2006), 3. Б. Самдан (Самдан, 2013), Н. С. Майнагашевой (Майнагашева, 2008), А. Л. Кошелевой (Кошелева, 2015), Ю. И. Чаптыковой (Чаптыкова, 2013), Л. В. Челтыгмашевой (Челтыгмашева, 2009).

Среди этих работ есть более значимые для становления данного подхода в современной науке: фольклористике и литературоведении. Так, В. Н. Захарову принадлежит заслуга введения новой научной дисциплины - этнопоэтики, которая по аналогии с этнолингвистикой «должна изучать национальное своеобразие конкретных литератур» (Захаров, 1998: 6). В. М. Гацак разработал научный инструментарий этнопоэтики, впервые в отечественной фольклористике он ввел понятие «этнопоэтической константы» (Гацак, 2000). В работах ученых его научной школы под этнопоэтическими константами подразумеваются «стилевые и сюжетно-повествовательные координаты изображаемого фольклорного мира» (там же: 15). Под руководством В. М. Гацака выросла плеяда тувинских фольклористов: С. М. Орус-оол, 3. Б. Самдан и др.

В современном литературоведении этнопоэтический подход использует У. Б. Далгат, выявляя фольклорные истоки (фольклорные мотивы и образы) творчества таких русских писателей, как 
И. А. Бунин, В. П. Астафьев, В. Г. Распутин и др. (Далгат, 2004). О. В. Зырянов в свете заявленного этноконфессионального подхода рассматривает теоретические и историко-литературные проблемы на примере произведений А. С. Пушкина, М. Ю. Лермонтова, Ф. И. Тютчев, А. А. Фета, Ф. М. Достоевского (Зырянов, 2018).

Неоценимый вклад в развитие этнопоэтики как нового исследовательского подхода внес авторитетный исследователь литератур Кавказского региона К. К. Султанов (Султанов, 2006). В исследованиях по национальным литературам Северного Кавказа К. К. Султанов говорит о важности опоры на принцип типологической общности, так как он способствует выявлению национальной художественной традиции, и одновременно подчеркивает природу индивидуального и национального в художественном творчестве региональных писателей (Султанов, 1996). В более поздних работах ученый утверждает, что способы выражения этнического в художественном тексте - доминантные образысимволы, базовые семантические и архетипические установки, которые являются «свидетельством онтологичности этнического»; в его понимании, этнический субстрат повествования выражает «культурный код», базисные ценности национального бытия (Султанов, 2006: 170).

В трудах данных ученых используются самые разные методы исследования этнопоэтики: контекстуальный и интертекстуальный анализ, мифопоэтика, мотивный и архетипический анализ, концепт-анализ, нарратологические и жанрологические исследования. Таким образом, этнопоэтический подход применяется в такой области исследования, где осуществляется поиск и объяснение того, как этнокультурные константы внедряются в текст и меняют его смыслы. Обобщая опыт проведенных исследований, отметим, что терминологическая вариативность понятий обусловлена их междисциплинарной природой, ведь основные национальные константы могут быть пространственными, временными, предметными, духовно-религиозными.

В данной статье мы используем «прецедентные» тексты ${ }^{1}$ современной тувинской и хакасской поэзии и их переводы для привлечения более широкого круга читательской аудитории. При написании данной статьи источниковой базой исследования стали сборники стихов как отдельных тувинских авторов: М. Б. Кенин-Лопсана ${ }^{2}$, А. А. Даржая ${ }^{3}$ Н. Ш. Куулара ${ }^{4}$, так и коллективные сборники ${ }^{5}$ Для исследования творчества хакасских авторов нами были использованы сборники стихов В. Г. Майнашева, изданные на хакасском и русском языках (в переводе автора) ${ }^{6}$; Н. М. Ахпашевой С. А. Майнагашева (Сибдей Том) ${ }^{8}$, сборник «Антологии хакасской поэзии»9.

\section{Этнопоэтическая основа литературы Саяно-Алтайского региона}

Этнопоэтический подход наиболее результативно используется в исследованиях, посвященных изучению творчества поэтов - представителей национальных литератур отдельных регионов. В последние годы в отечественном литературоведении заметно повысилось внимание к осмыслению локальных, в том числе региональных текстов как обладающих спецификой художественного пространства, системой мотивов, культурных кодов, обусловленных спецификой территории (географической, исторической, этнографической, социальной, мифологической).

\footnotetext{
${ }^{1}$ Ю. Н. Караулов под прецедентными понимает такие тексты, которые существуют в межпоколенной передаче, известны общенародному коллективу, наиболее значимы в познавательном и эмоциональном отношении (Караулов, 1987: 156).

${ }^{2}$ Кенин-Лопсан М. Б. Голоса: стихи. Кызыл: Тувинское книжное издательство, 1984. 141 с.

3 Даржай А. А. Молюсь утреннему свету: стихи и поэмы. Кызыл : Тувинское книжное издательство, 2007. 72 с.

${ }^{4}$ Куулар Н. Ш. Дангына : Стихи. Кызыл : Тувинское книжное издательство, 1996. 94 с.

${ }^{5}$ Антология тувинской поэзии: Тыва болгаш орус дылдарда / сост. Н. Ш. Куулар. Кызыл: Некоммерческое партнерство «Правник+», 2014. 461 с.; Благословение юрте. Стихи российских и зарубежных поэтов (2004) / под ред Н. О. Товуу; составители Н. Ш. Куулар, А. С. Казанцева. Кызыл: Центр развития национальной школы МОПО РТ. 98 с.

${ }^{6}$ Майнашев В. Г. Ирбен от. Стихтар. Агбан: Хызылчар книга изд-возынын Хакасиядагы полігі, 1979.96 с.; Майнашев В. Г. Кок саннары. Стихтар. Агбан: Хызылчар книга изд-возынын Хакасиядагы полігі, 1985.112 с.; Майнашев В. Г. Крашеные ковыли: стихи и поэмы. Абакан: Хакасское книжное издательство, 1995. 112 с.

${ }^{7}$ Ахпашева Н. М. Из памяти древней: стихи. Абакан: Хакасское книжное издательство, 2000. 32 с.; Ахпашева Н. М. Солярный круг. Стихи. Абакан: Хакасское книжное издательство, 1993. 120 с.

${ }^{8}$ Майнагашев С. А. (Сибдей Том) Илбек Чазы - Великая степь. Абакан: Хакасское книжное издательство, 1996. 96 c.

${ }^{9}$ Антология хакасской поэзии. Коллектив авторов. Абакан: Хакасское книжное издательство, 1961. 224 с.
} 
Методология исследования региональных текстов включает в себя разные научные направления, возникшие на стыке науки, искусства, философии (Галимова, 2015: 371). Ученые пришли к выводу о том, что для релевантности подобных исследований необходимо выявить те константы, которые присущи таким текстам в целом:

- наличие исходного мифа, лежащего в основе художественных построений;

- пространственно-временная организация, её сакральный характер;

- система лейтмотивов;

- сквозные образы (архетипические, мифопоэтические) (там же: 379).

Осмысление современного литературного процесса Саяно-Алтая на основе этнопоэтического подхода предполагает обращение к работам не только региональных критиков: К. Антошина (Антошин, 1982), У. Донгак (Донгак, 2013), Д. Куулар (Куулар, 2002), Н. Майнагашевой (Майнагашева, 2008), Л. Мижит (Мижит, 2006), А. Кошелевой (Кошелева, 2015), В. Карамашевой (Карамашева, 1995), В. Прищепы (Прищепа, 2006), 3. Б. Самдан (Самдан, 2013), М. Хадаханэ (Хадаханэ, 1986) и др., но и культурологов, философов: Г. Котожекова (Котожеков, 1995), Ч. Ламажаа (Ламажаа, 2013: 10) и др.

Этнопоэтический подход имеет междисциплинарный характер, так как исследует этнокультурные традиции в художественном тексте, которые выражаются через особенности менталитета, национального характера, религию, специфическую образность. Так, например, тувинский литературовед Л. С. Мижит, руководитель издания «История тувинской литературы» (История тувинской ... , 2013), изучая вопрос истоков традиционных форм трехстиший в современной поэзии, справедливо связывает этот вопрос с триадичной моделью мироздания, обосновывая общность культур народов Саяно-Алтая тем, что их космологические концепции исходят из древней религии тюрко-монгольских народов Центральной Азии и Сибири - шаманизма: «в первую очередь, это триадичная модель мироздания: Небо - Земля - Подземный мир (пространственная структура), прошлое - настоящее - будущее (временная структура) и центральная вертикальная ось мира, соединяющая три космические зоны» (Мижит, 2013: 13-14).

Процесс формирования историко-литературного мышления у писателей Саяно-Алтайского региона связан с фольклоризацией, введением в структуру произведений мифологических элементов, выполняющих многоаспектные художественные функции. Этнокультурные константы как параметры этнонациональной специфики пронизывают поэзию М. Баинова, А. Даржая, Н. Куулар, В. Майнашева, Э. Мижит, А. Кыштымова, Н. Ахпашевой, В. Серен-оол, З. Намзырай и др. Изучая произведения этих авторов, постараемся выявить основные константы обеих национальных поэтик: солнца, неба, степи, горы, курганов, юрты, коня, волка и др.

Исторические условия становления литератур Саяно-Алтая, а также богатые песенно-поэтические традиции, глубоко укоренившиеся в сознании и мировосприятии народа, способствовали тому, что поэты приспосабливали существующие фольклорные жанры - песни, благопожелания, пословицы - к новым условия развития литературы. Многие поэты для изображения современности использовали фольклорные формы: лексическое богатство, ритмические и изобразительные средства, приемы устного народного творчества, фольклорные мотивы.

Рассмотрим их на примере произведений тувинской и хакасской литератур.

\section{Этнопоэтические константы тувинской литературы}

В современной тувинской поэзии взаимоотношения фольклорных элементов и развитой системы современного литературного стиха сложны, многогранны и обусловлены существующими традициями использования фольклора, законами художнической избирательности, в основе которых лежит определенная идейно-эстетическая позиция писателя и индивидуальная природа его стиля. Исследования литературоведов, указанные выше, посвящены изучению мифо-фольклорных традиций в тувинской литературе в творчестве её основоположников: С. Тока, С. Сарыг-оола, О. Саган-оола; в произведениях авторов 1960-1990-х гг. М. Кенин-Лопсана, А. Даржая и др. В постсоветский период началось возрождение национальных традиций, о чем свидетельствует поэзия Н. Куулара, Э. Мижит, А. Уержа и др.

В нашей статье мы опираемся на известные современные исследования по фольклористике и литературоведению, в том числе на труды, раскрывающие художественно-стилевые традиции эпоса монголо-язычных и тюркоязычных народов Сибири (Кудияров, 2002); исследования, посвященные 
изучению тувинского фольклора (Орус-оол, 2001), а также периодизации тувинской литературы и типов художественного сознания в поэтике тувинской литературы (Донгак, 2013).

Современный тувинский фольклорист и литературовед 3. Б. Самдан, последовательно занимаясь изучением этнопоэтических традиций, отмечает: «живучесть фольклорных традиций объясняется тем, что основополагающей стержневой идеей, подпитывающей эти корни, была и остается идея неразрывности человека и природы» (Самдан, 2010: 269).

Серьезным вкладом в исследование этнопоэтического своеобразия тувинской литературы является диссертация Т. Очур, посвященная прозе С. Сарыг-оола, цель которой заключалась в выявлении специфики национального мировидения в художественной структуре произведений писателя, в определении констант созданной писателем модели мира (Очур, 2008). Такими константами тувинской национальной картины мира исследователь считает образы-символы: степи, горы, реки, юрты, очага (там же: 12-14).

Наиболее ощутимо этот стиль закреплен в поэзии М. Кенин-Лопсана, Э. Мижита, В. Серен-оола, А.Даржая, 3. Намзырай, М. Доржу, А. Уержаа, Н. Куулара и др., жанрово-стилистическая природа творчества которых ведет к лирико-философскому постижению национального характера, настоящего и прошлого родной земли, к передаче национальной психологии и своеобразию национального мышления. Устойчивые нормы поведения, этикет, ритуалы, отображенные в их творчестве, обращение к фольклорным приемам становятся основой раздумий о прошлом и настоящем родной культуры, об этнической самоидентификации.

В творчестве нашего современника Монгуш Кенин-Лопсана явно ощутимы фольклорные приемы сравнения, метафоры, сам поэтический строй.

Элик безин турлаглыг дээр,

Элих чуртун кагбас дижир.

Кезек-кезек авамның өөн

Кедергейин сактып кээр мен ${ }^{1}$.
Так говорится в моей стороне:

Даже косуля не хочет оставить

Край, где пришлось ей родиться, - а мне

Как материнскую юрту не славить...

(Пер. И. Фонякова) $)^{2}$

Опираясь на эстетику фольклора и подчинив ее своим идейно- художественным задачам, М. КенинЛопсан в этом стихотворении «Авамнын өө» («Юрта матери») развивает традиции народной поэзии, в основе образной выразительности используется традиционный для фольклора параллелизм поэтических образов. Мысль о нераздельной слитности человеческого и природного бытия составляет глубинный философский смысл этих строк. Центральный образ этого стихотворения - өг (юрта). Это и одна из устойчивых констант, и в то же время образ-символ Дома, Времени, его хода, знак прошлого и будущего:

Баштай үнгээн черим боорга,

Баштай турган уям боорга,

Мактаар чаглаам - авамның өө.

Ынакшаанда, хорадаанда,

Ырлап чоруур ырым угу... ${ }^{3}$
Юрта - исток мой, начало начал,

Юрта, в которой все вещи - живые.

Ты - моя песня, а я - твой певец.

(Пер. И. Фонякова) $)^{4}$

Для поэта, с одной стороны, юрта - это реальность, место, в котором он родился и жил; с другой стороны, это сакральное пространство, олицетворяющее движение времени, свойственное национальному художественному мышлению. Образ юрты дарит ощущение единства мира и себя, поэтическое осознание связи времен и поколений: лирический герой - авторское «Я» и старшее поколение - «мои отец и мать».

\footnotetext{
${ }^{1}$ Кенин-Лопсан М. Б. Голоса: стихи. Кызыл : Тувинское книжное издательство, 1984. С. 140.

${ }^{2}$ Благословение юрте. Стихи российских и зарубежных поэтов / под ред Н. О. Товуу; составители Н. Ш. Куулар, А. С. Казанцева. Кызыл: Центр развития национальной школы МОПО РТ, 2004. С. 31.

${ }^{3}$ Кенин-Лопсан М. Б. Голоса ... С. 140.

${ }^{4}$ Благословение юрте ... С. 32.
} 
Это мироощущение уходит корнями в эстетику народного поэтического творчества, в котором мир предстает цельным и нераздельным. Стихотворению М. Кенин-Лопсана присущ очень обстоятельный и неторопливый ритм, отражающий философскую созерцательность мышления. Особенность его художественного мышления - растворение личного начала, подчинение его общему ритму бытия своего народа.

В системе традиционных этнопоэтических образов важную роль играют обряды и ритуалы, обращение к которым дает возможность раскрыть непреходящий смысл архаических норм поведения, ритуала, а значит, и мышления. Например, в стихотворении Антона Уержаа «Артыжап көр» («Овейте дымом артыша») воссоздается философия национального бытия - ритуал очищения с помощью священного артыша, дымом которого изгоняется дух болезни:

Алаш хемниң эзиминден
Ачам чулуп эккеп кааны
Ыдык үнүш хуулгаан күжү
Аарагны өөвүстен
Арыдыптар дээрзинге
Ынак авам бүзүрээн боор...

Над артышом - багульником таежным Шептала мама древние слова.

На камне плоском костерочка стожик Зажгла в тот час, когда кричит сова...

(Пер. Ю. Вотякова)².

Артыш (можжевельник) - сакральное растение (Бавуу-Сюрюн, Широбокова, Сандан, 2018: 42). В стихотворении образ артыша разрастается до многозначного символа, олицетворяющего и материнскую любовь: «Не суеверье, вовсе нет, я знаю, / Недуг прогнало из груди моей, / А материнская любовь» ${ }^{3}$, и «отраженье дружбы и печали, страсти и добра» - «сердце» поэта: «Сердце мое тихое горит, / Освещая вам дорогу к дому» 4 , и символ родного края. В данном стихотворении формой выражения этнопоэтической константы становится образ-символ, с помощью которого представлен духовный мир своего народа и особенности его мировосприятия.

Не менее распространенными константами эпоса, различающимися своей национальной спецификой, национальными верованиями и представлениями народа, является описание обряда угощения.

Такой традиционный для восточных культур обряд чаепития описан в элегиях Николая Куулара «Өөм» («Моя юрта») и «Авам шайы» («Чай матери») 5 . В элегии «Юрта» ощутимы традиционные формулы фольклора, коллективный автор которого создавал героический эпос: у подножья хребта, в широкой степи 6 . Традиционный образ юрты овеян теплым лирическим чувством благодаря приему олицетворения:

Авазын эмген эмиим ышкаш

Ава черим борбак тейи,

Ыдык төрел чыды сиңген... ${ }^{7}$
Юрта с женскою грудью схожа:

в ней тепло материнства и родства молоко...

(Пер. Ю. Вотякова) ${ }^{8}$

Художественный образа юрты расширяется за счет ретроспективности описания: от детских воспоминаний как знака прошлого - к настоящему и будущему времени.

\footnotetext{
${ }^{1}$ Уержаа А. Артыжап көр [Овейте дымом артыша] // Благословение юрте. Стихи российских и зарубежных поэтов / под ред Н. О. Товуу; составители Н. Ш. Куулар, А. С. Казанцева. Кызыл : Центр развития национальной школы МОПО РТ, 2004. С. 74.

${ }^{2}$ Там же.

${ }^{3}$ Там же.

${ }^{4}$ Там же.

${ }^{5}$ Антология тувинской поэзии: Тыва болгаш орус дылдарда / сост. Н. Ш. Куулар. Кызыл: Некоммерческое партнерство «Правник+», 2014. С. 76-77.

${ }^{6}$ Там же. С. 76.

${ }^{7}$ Там же. С. 77.

${ }^{8}$ Там же. С. 76.
} 
В элегии «Материнский чай» преобладают глагольные формы настоящего времени: «Ынак авам сарыг шайын, Саарып тура...» - «Там желтый чай заваривает мать...»1 , что создает интонацию некой повторяемости, вечности этого традиционного ритуала. Близость авторского стиля фольклорной эстетике определяется характером эпитетов - конкретным и своеобычным: сарыг - желтый (то есть без молока), изиг шайын - горячий, дазыл хуваа - свежий.

Эти стихи рождены народной жизнью, в них поэт, прибегая к выразительным средствам устной народной поэзии, стремится к поиску новых форм синтеза их с поэтикой современного литературного стиха, философски осмысляя в лирике «вечные» темы бытия: разлуки и встречи, расставания и ожидания.

В лирическом цикле Александра Даржая «Өгге йорээл» («Благодарность юрте») лирико-философские раздумья о жизни по своей сюжетно-образной структуре близки народным преданиям, героическим песням. Здесь ощутимо родство тем и мотивов, близость всей художественной материи национальному фольклору.

Стихотворение композиционно состоит из двух частей, построено на противопоставлении прошлого и настоящего, поэтому в системе поэтических образов, описывающих далекое историческое прошлое, прослеживаются давние традиции устного народного творчества. А. В. Кудияров считает, что одним из постоянных эпических общетюркских символов-понятий для обозначения «родных мест» сибирских народов (тувинцев, хакасов, алтайцев) является чер-суг (земля-вода) (Кудияров, 2002: 121). На наш взгляд, характеристика пространства и времени в данном стихотворении наделена узнаваемыми чертами национального пейзажа: «В слиянье семи рек, в степи широкой...» (землявода) и образами далекой старины, память о которой сохранили только курганы. Степь, курганы, горы - не только тувинские, но и общетюркские образы-символы (Очур, 2008: 12-14).

Көшкүн тыва кидис өглер чырык хүндүс Хөрлээ отка чалбыышталдыр хып-даа чораан. Кыпчактың өө даңгаар эртен чалбыыш оттан Кызыл хаяа өңүн хунаап, хып-даа турган ${ }^{2}$
Средь бела дня пылала жарко юрта, Поставленная кочевым тувинцем, А юрта кипчака под утро тоже Кровавою зарею полыхала...

(Пер. Е. Евпатова $)^{3}$

Центральный художественный образ стихотворения - ак-көк (сизый дым) - также является многозначным образом-символом, олицетворяющим домашний очаг, «щедрый чай», покой и мир. В этих стихах, имеющих форму духовного наставления, обобщен жизненный опыт поэта, который озабочен будущим родного этноса. Внимание А. Даржая сосредоточено не на личностных проблемах, он видит свой нравственный долг, на наш взгляд, в создании философии выживания в век ядерного оружия. Народные традиции творчески преломляются в художественной структуре его поэзии, определяя особенности его стилевой концепции, для которой свойственны простота и безыскусственность образов, ассоциативных сцеплений, поэт возвышает их, чтобы перевести в другой план - поэтический и философский. Поэт старается сближать разные повествовательные времена, это позволяет укрупнять масштабы повествования, придать ему многомерность эпоса, используя прием синтаксического параллелизма:

\footnotetext{
1 Куулар Н. Авам шайы [Чай матери] // Антология тувинской поэзии: Тыва болгаш орус дылдарда / сост. Н. Ш. Куулар. Кызыл: Некоммерческое партнерство «Правник+», 2014. С. 77.

${ }^{2}$ Даржай А. Өглеривис ак-көк ыжы [Сизый дым наших юрт] // Антология тувинской поэзии: Тыва болгаш орус дылдарда / сост. Н. Ш. Куулар. Кызыл: Некоммерческое партнерство «Правник+», 2014. С. 7.

3 Даржай А. Өглеривис ак-көк ыжы [Сизый дым наших юрт] // Благословение юрте. Стихи российских и зарубежных поэтов / под ред Н. О. Товуу; составители Н. Ш. Куулар, А. С. Казанцева. Кызыл : Центр развития национальной школы МОПО РТ, 2004. С. 56.
} 
Бөгүн ону бодап кээрге, хөй-ле бодал

Башка кирип, дүвүренчиг дойлуп кээр-дир.

Амыдырал кара дүнче шилчип болур

Амгы шагның дайыны-даа сүртенчиг$\partial u p^{1}$.
Когда сейчас подумаешь об этом

И сопоставишь с нынешними днями, тревожно станет: может превратиться

Жизнь в дым в горниле общего самоубийства...

(Пер. Е. Евпатова) $)^{2}$.

Именно здесь, на уровне художественного обобщения пролегают внутренние связи поэтики с фольклорным художественным мышлением. И здесь, прежде всего, важно проследить, как преломляется в его творчество судьба человека и народа - этот важнейший момент фольклорного сознания:

Бамбук чадыр, кирбиш бажың, кидис өглер Чанданыңдан ак-көк ыжы дээрже үнүп, Шайы хайнып, кезээ шагда мөңзе турар 3.
И потому пускай струится в небо, От очагов, где вкусно пахнет пищей, И ваших юрт, и наших сизый дым!

(Пер. Е. Евпатова) $)^{4}$.

У Александра Даржая немало стихотворений, посвященных Туве, где одной из главных констант является образ Ие-Чер («Мать-Земля»), сакральный характер которого определяется тем, что «отождествляя родную землю со своей матерью, лирический герой А. Даржая олицетворяет ее с истоком бытия, прародительницей...» (Чендекова, 2017: 204). В стихотворении «Вера в себя» автор признается: «...Кажется, теперь / Нет непосильной ноши для меня, / А сила прибывает каждый час / Зачем она? Чтоб матери-Земле / Помочь...»

На наш взгляд, глубоко поэтично раскрыл сакральную философию тувинской юрты Эдуард Мижит в лирико-философской поэме «Өг» («Юрта»):

Өгбелерниң хайырлааны тыва өгнүң,
Эжиин ажып, эргин артап, мөгейбишаан,
кирээлиңер...6

Откроем же дверь и, шагнув за Порог, с поклоном войдем в тувинскую юрту - великий дар наших предков...

(Пер. Э. Мижит) ${ }^{7}$.

В пяти частях поэмы описан один из ключевых образов юрты: «Дверь», «Порог», «священный Багана» (опорный шест), «священный очаг». Каждый из этих образов в поэме приобретает символическое значение: «Дверь» и «Порог» как символы начала и конца жизни, «священный Багана» как символ священного очага, души человеческие как птицы, а звезды символизируют человеческие мечты, порыв к высокому, полет души. В этой поэме наряду с тончайшим лиризмом Э. Мижиту удалось раскрыть философский смысл непреходящих ценностей устойчивых, архаичных норм жизни, этикета, мышления, национальных традиций тувинского народа.

\footnotetext{
${ }^{1}$ Даржай А. Өглеривис ак-көк ыжы [Сизый дым наших юрт] // Антология тувинской поэзии: Тыва болгаш орус дылдарда / сост. Н. Ш. Куулар. Кызыл: Некоммерческое партнерство «Правник+», 2014. С. 7.

${ }^{2}$ Там же.

${ }^{3}$ Даржай А. Өглеривис ак-көк ыжы [Сизый дым наших юрт] // Благословение юрте. Стихи российских и зарубежных поэтов / под ред Н. О. Товуу; составители Н. Ш. Куулар, А. С. Казанцева. Кызыл : Центр развития национальной школы МОПО РТ, 2004. С. 56.

${ }^{4}$ Там же. С. 49.

${ }^{5}$ Там же.

${ }^{6}$ Мижит Э. Өг [Юрта] // Благословение юрте. Стихи российских и зарубежных поэтов ... С. 19.

${ }^{7}$ Там же. С. 10.
} 
Таким образом, обращаясь к произведениям тувинских поэтов в рамках заявленной проблемы исследования, мы выделяем такие этнопоэтические константы, которые, с одной стороны, являются традиционным способом репрезентации национальной тувинской картины мира: небо, матьземля, степи, горы, реки, а, с другой, отмечаем индивидуально-авторские образы-символы, которые являются своеобразной интерпретацией художником-творцом национального художественного сознания. К таким индивидуально-авторским образам-символам, подчеркивающим самобытность тувинского национального литературного процесса, на наш взгляд, можно отнести: материнская (отиовская, дедовская) юрта, артыш, зеленый чай, сизый дым, очаг, дверь и порог юрты, опорный шест Багана, звезды и др.

\section{Этнопоэтические константы хакасской литературы}

Известный хакасский литературовед А. Л. Кошелева к способам репрезентации национальной идентификации относит такие константы национального хакасского бытия, как Небо, Степь, Курган, Ветер, Тайга (Кошелева, 2015: 155-157).

Для выявления наиболее характерных этнопоэтических констант в современной хакасской поэзии мы обратились к творчеству тех авторов, чья личность была сформирована под влиянием культуры родного этноса: Н. Ахпашевой, В. Майнашева и С. Майнагашева.

На сегодняшний день, пожалуй, одним из немногих поэтов Хакасии, в творчестве которого последовательно разрабатывалась тема родной земли, ее прошлого, настоящего и будущего является $B a-$ лерий Майнашев. Ощущение глубинных взаимосвязей времен и рождает индивидуальное мышление В. Майнашева. Поэзия В. Майнашева - яркий пример билингвального творчества. В. Майнашев закончил Литературный институт им. А. М. Горького, (г. Москва), с 1990 г. возглавлял Союз писателей Хакасии. Поэт стал одним из первых переводить свои стихи с хакасского языка на русский, добиваясь адекватности даже в тех случаях, когда в русском языке не находилось эквивалентного значения хакасскому понятию.

В поэзии В. Г. Майнашева возникает своеобразный символ Хакасии - ирбен от (богородская трава, чабрец). Не случайно, ее именем он назовет и одно из лучших своих стихотворений, и первый свой сборник (Майнашев, 1995). Символика этого образа связана с традиционным мировоззрением тюрков. У тюркских народов эта трава считалась священной, ее дымом освящали жилище и скот. Так, например, у хакасов, богородской травой окуривали ызых - ритуального коня. «Ызых - привилегированное, священное животное в стаде, чаще всего конь. Его, возводя в звание, окуривали богородской травой, в хвост и в гриву шаман вплетает ему ленты» (Бутанаев, Верник, Ултургашев, 1999: 32).

В. Г. Майнашев, выросший в самом сердце хакасской земли, с детства знал об этой чудо-траве:

Курген. Халсарыг. Таг аразы.

Чалгызаан чазаг мин не парчам.

Тустар чызы - ирбен от чазы

Чуреемі пазох сулгапча ${ }^{1}$.
Курган. Ковыль. Горы

Иду пешком я один

Запах времен - богородской травы запах

окутывает снова сердце мое

Каждое стихотворение поэта, наполненное национальным колоритом, картинами хакасского ландшафта, раскрывает тему одиночества человека, затерявшегося в бескрайней ночной степи.

Еще одним ярким символом хакасской земли в поэзии В. Майнашева являются кун чахаяхтары (жарки):

${ }^{1}$ Майнашев В. Ирбен от. Стихтар. Агбан: Хызылчар книга изд-возынын Хакасиядагы полігі, 1979. С. 44-45.

${ }^{2}$ Майнашев В. Г. Крашеные ковыли: стихи и поэмы. Абакан: Хакасское книжное издательство, 1995. С. 50. 
Пазох койче кун чахаяхтары.

О хайди орта чон оларны тіпче,

Часхы читсок, пістінарыгларда

Мунар кунічіктер койібісче 1.
Вновь брожу я по лесам зеленым

Над бездымным пламенем жарков,

И кукушки голос отдаленный, Словно сердце вешнее лесов

(Пер. В. Майнашева) ${ }^{2}$.

В. А. Карамашева считает, что система ценностей В. Майнашева определяется целью «понять сущность Вселенной, мира в целом» (Карамашева, 1995: 6). Поэтический мир В. Г. Майнашева - мировоззренческая система, способная вместить опыт русской классики и художественное национальное сознание, приметы древнего язычества и многие особенности национальной традиции. С одной стороны, он обнажает языческие корни хакасского миропонимания, бережно и уважительно охраняет его от исчезновения, фиксируя его наличие в жизни современного человека. Не случайно, поэт и, думается, не в шутку, а всерьез называл себя «последним шаманом», отдавая себя, свой поэтический дар «на суд достойный шаманов» «всех забытых селений»:

Эй, чеек айдас хамнар

Прай ундулган ааларнын!

Озеннер-састардан ${ }^{3}$.
Эй, лихие шаманы

Всех забытых селений,

Выползайте туманом

Из логов и ущелий.

(Пер. В. Майнашева) 4 .

Вместе с тем, меряясь своей силой с шаманами, ощущает свое преимущество:

Чох идіп санай хыялларны,

Агын тудыста хамнан,

Сірерзер, чаргычыларзар,

Улуг чииииніснен айланам 5 .

\section{У коварного духа}

Мощь моих песнопений

Все заблудшие души

Отобьет непременно...

(Пер. В. Майнашева) ${ }^{6}$

В этом стихотворении без названия Валерий Майнашев, с одной стороны, демонстрирует независимость поэта, его самодостаточность, равноправие его слова с шаманской силой, а с другой все же признает роль шаманов как достойных судей своих стихов. Возникающее противоборство, мерение силами - ситуация совсем не мировоззренческого плана, а скорее художнического. Поэт устанавливает свое право на самостоятельность мирочувствования и художественное его выражение.

В поэтическом сборнике В. Майнашева «Крашеные ковыли» одним из значимых является стихотворение «XX век», в хакасском сборнике его название дано по первой строке: «Койібісті хой порчозы...» В этом стихотворении ключевым является образ кургана, в котором может быть захоронен главный герой героического эпоса «Албынжи»:

Эй, когде чусчеткен нанчы,

Комес тее истек се,

Хайди поларзын, Албынчы

Ам кургеннен сых килзе?'
Эй, погоди приятель, Ты мне одно скажи.

А если вдруг некстати

Проснется Албынжи?

(Пер. В. Майнашева) $)^{2}$.

\footnotetext{
${ }^{1}$ Майнашев В. Г. Крашеные ковыли: стихи и поэмы. Абакан: Хакасское книжное изд-во, 1995. С. 75.

${ }^{2}$ Там же.

${ }^{3}$ Майнашев В. Г. Кок саннары. Стихтар. Агбан: Хызылчар книга изд-возынын Хакасиядагы полігі, 1985. С. 48.

${ }^{4}$ Майнашев В. Г. Крашеные ковыли: стихи и поэмы. Абакан: Хакасское книжное издательство, 1995. С. 50.

${ }^{5}$ Майнашев В. Г. Кок саннары. Стихтар. Агбан: Хызылчар книга изд-возынын Хакасиядагы полігі, 1985. С. 49.

${ }^{6}$ Майнашев В. Г. Крашеные ковыли: стихи и поэмы. Абакан: Хакасское книжное издательство, 1995. С. 50.
} 
В данном стихотворении курган символизирует и героическое прошлое Хакасии, и её будущее, поскольку в хакасской мифологии говорится о том, что герои-алыпы ${ }^{3}$ спят до поры и проснуться, когда надо будет защитить свой народ. В лирике хакасских поэтов также часто используется описание языческих обрядов: поклонение огню, культ огня, почитаемый древними тюрками (стих. Майнашева «Песня о друге» («Нанчыдаңарыр»): «Иргі песте от успинча, / Сарығ тонағчы сығырчатхан осхас... «В старой печке огонь не унять / - Будто рыжий разбойник свистит...» $\left.{ }^{4}\right)$. В. Майнашев своеобразно воспринимал и осмысливал традиционную модель мира своих предков. Ему как поэту-жизнелюбу более до́роги серединный и верхний миры, цветовые символы которых наполняют большинство его стихотворений. Например, описание весеннего состояния природы поэт передает в стихотворении «Чир усхунганы» («Пробуждение») с помощью метафоры кок тук (зеленый пух):

Харах козше чир хубулча Чазылар-таглар когерсче

Агастар кок тукнен чабынча ${ }^{5}$
На глазах земля преображается, Степи и горы зеленеют,

Деревья покрываются зеленым пухом

(Пер. В. Майнашева) ${ }^{6}$.

В стихотворении «Уходят кони» (в оригинале без названия) цветовой эпитет хызыл (красный) «Хайди хызыл тигір хызыл чалыннан...» («Усталое в степи садится солнце... По ковылям вдали погонщики на красном горизонте...») - символизирует гибель природного мира, становится цветом смерти. Вполне обоснованно, своеобразно традиционному мировоззрению хакасов, поэт опасался запада, означавшего осень, закат, вторую половину жизни, мир предков.

В поэзии В. Майнашева сравнительно ощутимо отражена философия шаманизма, при этом нельзя сказать, что шаманизм безоговорочно воспринимается поэтом как целостная религиозная система, становясь основой его поэтического мира, вместе с тем мировоззренческий фундамент В. Майнашева в большей мере укрепляется этой первой, естественной религиозной системой.

Еще одним автором, черпающим вдохновение в прошлом своей малой родины, является Наталья Ахпашева. Несмотря на то, что Н. Ахпашева создает свои произведения только на русском языке, именно этнопоэтические константы в её поэзии позволяют без труда определить её этническую принадлежность и ментальные истоки, генетическую связь с которыми подчеркиваеся поэтессой постоянно. Наиболее известны её стихи «Чингизиды», «Гунны», «Тавро», «Салбык», «Древнее изваяние».

Художественный мир Н. Ахпашевой в его энопоэтическом аспекте наиболее ярко представлен в сборнике «Солярный круг»7. Программным в этом сборнике является стихотворение «Салбык». Большой Салбыкский курган - один из древнейших символов Хакасии, ученые относят этот курган к скифским временам, но некоторые считают его более древним, чем египетские пирамиды. Как известно, большой вклад в изучение этнографии и культуры Хакасии внесли немецкие ученые XVII-XIX веков. Первым описал Большой Салбыкский курган в 1739 г. российский учёный Г. Ф. Миллер во время академической экспедиции по Сибири 1733-1743 гг. (Миллер, 1999: 503).

В стихотворении «Салбык» Н. Ахпашева описала обряд трупосожжения:

На голый курган у дороги

Где дышит полынью простор

слетелись голодные боги

на мой погребальный костер ${ }^{1}$.

Л. Р. Кызласов воспроизвел подобный обряд: «Это были могилы воинов-конников, с которыми на погребальный костер укладывали наборные узды и украшенные накладками с серебряной инкрустацией седла...» (Кызласов, 1969: 45).

\footnotetext{
${ }^{1}$ Майнашев, В. Кок саннары. Стихтар. Агбан: Хызылчар книга изд-возынын Хакасиядагы полігі, 1985. С. 25.

${ }^{2}$ Майнашев В. Г. Крашеные ковыли: стихи и поэмы. Абакан: Хакасское книжное издательство, 1995. С. 22.

${ }^{3}$ Сагояков Н. Н. Хакасские мифы. Абакан: Хакаское книжное издательство, 2010. С. 134.

${ }^{4}$ Майнашев В. Г. Кок саннары. Стихтар. Агбан: Хызылчар книга изд-возынын Хакасиядагы полігі, 1985. С. 15.

${ }^{5}$ Там же. С. 46.

${ }^{6}$ Майнашев В. Г. Крашеные ковыли: стихи и поэмы. Абакан: Хакасское книжное издательство, 1995. С. 56.

${ }^{7}$ Ахпашева Н. М. Солярный круг. Стихи. Абакан: Хакасское книжное издательство, 1993.
} 
Обряд захоронения у Н. Ахпашевой представлен как языческий:

Я дымом седым поднимался,

К таким же прозрачным, как $я$

Но медлил и не растворялся

Над белой волной ковыля².

Многозначность этого образа определяется еще и тем, что Салбык - не только образ-символ былого могущества, его значимость связана с традиционным представлением о мировой горе - оси сакрального мира, соединяющей верхний мир с миром людей и нижним миром духов; это и место, где проводятся шаманские обряды до настоящего времени.

В другом стихотворении без названия «Я стучу колотушкою в бубен...» ${ }^{3}$ лирическая героиня стихотворения Н. М. Ахпашевой - шаманка. Так поэтесса подчеркивает свою генетическую связь с языческим прошлым. Во многих стихах этого сборника звучит мотив этнической солидарности Н. Ахпашевой с предками, поэтического осмысления древнехакасской истории: она гордится своим кровным родством с языческими богинями, чьи глаза «к вискам заужены прекрасно, называя себя их «последней сестрой» ${ }^{4}$

Многие авторы современной хакасской литературы ориентированы на мифофольклорный субстрат своих национальных литератур в силу того, что стали осознавать неизбежность конфликта между довлеющей цивилизацией и ценностями своей традиционной культуры. С этой точки зрения, Сибдей Том (псевдоним Сергея Майнагашева) абсолютно верно это почувствовал и сделал первые ощутимые шаги в данном направлении. Сибдей Том сознательно пишет не только на хакасском, но и на русском языке, подчеркивая свою бикультурность и желая пропагандировать ценности древнехакасской культуры для русскоязычного читателя.

Сибдей Том стремится соединить этнокультурный фактор с литературной традицией, что стало возможно благодаря выживанию традиционного культурного комплекса, таким образом, чтобы доминировала хакасская национальная идея («оставь европейский накал стихотворений»5). По существу, он наследует существующую традицию воинской доблести предков, преодолевая её и своеобразно трансформируя:

Тебе! Покорять континент! И вместо культуры сабель

Нести музыку бубна...6

Сибдей Том внимателен к опыту предков, который он не просто, вооружаясь им, принимает на веру, но переоценивает:

мои предки, казалось бы

Были глупы в противлению Западу,

Не оставили громких записок! ${ }^{7}$

Сибдей Том выступает прилежным учеником своих предков, подчеркивая генетическое родство в понимании тайны жизни и смерти, которую достойный из потомков должен сохранить в себе тем самым как бы продлевая существование вечной загадки бытия. Поэт подчеркивает суетность и бренность («недолговечность наглядна») человеческих устремлений.

Поэт признает торжество мудрости своего народа, гордится им. Он занимает достойную позицию человека, решившего восстановить историческую справедливость: «Азия равна Европе» (Прищепа, 2006: 247). Сибдей Том, по существу, утверждает идею равнодостойности своего народа с народами европейскими. Он возвращает к столь важным для любого хакаса понятиям их изначальный, всеобъемлющий смысл. Его задача - увидеть и попытаться истолковать вечные для сына степей темы. Уже только этот подход заслуживает внимания, ибо он предполагает выход на рассмотрение главных вопросов бытия.

\footnotetext{
${ }^{1}$ Ахпашева Н. М. Солярный круг. Стихи. Абакан: Хакасское книжное издательство, 1993. С. 13.

${ }^{2}$ Там же.

${ }^{3}$ Там же. С. 92.

${ }^{4}$ Там же.

${ }^{5}$ Майнагашев, С. (Сибдей Том) Илбек Чазы - Великая степь. Абакан: Хакасское книжное издательство, 1996.

C. 15 .

${ }^{6}$ Там же. С. 8.

${ }^{7}$ Там же. С. 10.
} 
На наш взгляд, в поэзии Сибдей Тома наиболее часто используются следующие слова-образы, многие из которых являются этнопоэтическими константами: Степь, Небо, Восход, Волк, Камни (читай Курганы), Поле, Путь, Ветер, Родина. Особое место в этом ряду имеет прежде всего слово «Бог» (Худай по-хакасски - «Бог огня, воды, неба»). Небо у Сибдея Тома - это не простой образ-символ. Небо Великое, чистое; Небо - всевышний, старое Небо (в чем очевидны отголоски тэнгрианства). Такое наличие этнопоэтических констант, несущих основной смысл, живет в поэтическом мире Сибдея Тома органично, ненавязчиво, не оставляя ощущения семантической перенасыщенности и случайности.

Таким образом, осмысление творчества современных хакасских поэтов сводится к пониманию того, что без глубины познания национального, укорененности в нем невозможна духовная зрелость, онтологичекая достаточность. Главными скрепами хакасской национальной картины мира являются традиционные для народов Саяно-Алтая этнопоэтические константы солнца, неба, степи, горы, курганов, коня, волка и др. Но, появляются индивидуально авторские образы-символы, без которых невозможно представить художественный мир отдельного художника слова и национальную хакасскую картину мира: богородская трава, жарки, ковыль, герои-алыпы, Салбык, шаман, бубен, Запад-Восток, Европа-Азия и т. д.

\section{Заключение}

В силу того, что литературы Саяно-Алтая на современном этапе по-прежнему ориентируются на мифофольклорный субстрат своих национальных культур, этнопоэтический подход является наиболее адекватным способом рефлексии их поэтики.

В творчестве современных тувинских и хакасских авторов, по нашим наблюдениям, общими маркерами национального менталитета, миропонимания являются этнопоэтические константы: солнце, небо, степи, горы, курганов, юрты, коня, волка и др., которые свидетельствуют об общности происхождения, родственности обеих культур. Но авторские художественные картины мира, созданные тувинскими и хакасскими поэтами, всё же отличаются индивидуальными авторскими образами-символами. Именно в них заложена этнокультурная составляющая, распредмечивающая главный смысл стихотворений, что позволяет более глубоко осознать особенности обеих национальных литератур - тувинской и хакасской.

В результате проведенного исследования нами выявлены индивидуально-авторские образы-символы, которые являются своеобразной интерпретацией художником-творцом тувинского национального художественного сознания, к таким индивидуально-авторским образам-символам, подчеркивающим самобытность тувинского национального мировидения, на наш взгляд, принадлежат: материнская (отцовская, дедовская) юрта, артыш, зеленый чай, сизый дым, звезды, дверь, порог (юрты), священный шест Багана и др.

Проведенное исследование позволило выявить и ключевые образы-символы современной хакасской поэзии, которые являются индивидуально авторскими, но без них невозможно представить художественный мир отдельного художника слова и хакасскую картину мира: богородская трава, жарки, ковыль, герои-алыпы, Салбык, бубен, шаман, Запад-Восток, Европа- Азия и т. д.

Таким образом, исследуя этнопоэтические особенности художественного сознания современных тувинских и хакасских авторов, мы обнаружили, что для них в равной степени характерно обращение к национальным истокам, а также обостренное внимание к национальным традициям - историкокультурным и этнопоэтическим, к эстетическим ценностям, накопленным в фольклоре и литературе. Авторы Саяно-Алтайского региона сохранили свою национальную идентичность, принимая за основу национального чувства эстетический, исторический опыт прошлого, выступая прилежными учениками своих предков. Проведенное исследование подчеркивает генетическое родство обеих литератур, основанное на родственности их древних культур, на понимании тайны жизни и смерти, которую достойный из потомков должен сохранить в себе - тем самым как бы продлевая существование вечной загадки бытия. По существу, каждый из авторов тувинской и хакасской литератур является национальным поэтом, вскрывающим потаенные мировоззренческие и эстетические богатства своего древнего народа.

\section{СПИСОК ЛИТЕРАТУРЫ}

Алефиренко, Н. Ф., Голованева, М. А., Озерова, Е. Г., Чумак-Жунь, И. И. (2012) Текст и дискурс: учебное пособие для магистрантов. М. : Флинта ; Наука. 232 с. 
Антошин, К. Ф. (1982) У истоков жизни: о современной литературе Хакасии, Тувы, Горного Алтая, Красноярского края. Красноярск : Красноярское книжное издательство. 96 с.

Бавуу-Сюрюн, М. В., Широбокова, Н. Н., Самдан, А. М. (2018) Названия лекарственных растений Тувы в словарях // Новые исследования Тувы. № 4. С. 30-46. DOI: https://doi.org/10.25178/nit.2018.4.2

Балданов, С. Ж. (1983) Общность национальных литератур Сибири // Взаимодействие литератур народов Сибири / отв. ред. Г. И. Ломидзе. Новосибирск : Наука, Сибирское отделение. 272 с. С. 147-152.

Балданов, С. Ж. (2005) Формула единства сибирских национальных литератур и формы межлитературных коммуникаций // Сибирь - единое фольклорно-литературное полиэтническое пространство : в 2 ч. / отв. ред. С. Ж. Балданов. Улан-Удэ : ГУП «ИД» «Буряад унэн». Ч. І. Вып. І. 180 с. С. 5-9.

Бикмухаметов, Р. Г. (1983) Орбиты взаимодействия. М. : Советский писатель. 240 с.

Бутанаев, В. Я., Верник, А. А., Ултургашев, А. А. (1999) Народные праздники Хакасии : учебное пособие. Абакан : Изд-во ХГУ им. Н. Ф. Катанова. 208 с.

Галимова, Е. Ш. (2015) К вопросу о методологии исследования локальных (городских и региональных) литературных текстов (на примере Северного текста русской литературы) // Сибирская идентичность в зеркале литературного текста: тропы, топосы, жанровые формы XIX-XX вв. / отв. ред. Н. В. Ковтун. М. : Флинта ; Наука. 456 с. C. 380-395.

Гацак, В. М. (2000) Северные этнопоэтические константы // Народная культура Русского Севера. Живая традиция: Материалы республиканской школы-семинара Вып. 2 / отв. ред. Н. В. Дранникова, Ю. А. Новиков. Архангельск : Изд-во Поморского государственного университета. 136 с. С. 7-10.

Далгат, У. Б. (2004) Этнопоэтика в русской прозе 20-90-х гг. ХХ века (Экскурсы). М. : ИМЛИ РАН. 212 с.

Донгак, У. А. (2013) Предпосылки зарождения тувинской литературы // История тувинской литературы: в 2 т. / отв. ред. К. А. Бичелдей. Новосибирск: Издательство СО РАН. Т. 1. 266 с. С. 103-108.

Захаров, В. Н. (1998) Православные аспекты этнопоэтики русской литературы // Евангельский текст в русской литературе XVIII-XX веков / отв. ред. В. Н. Захаров. Вып. 2. Петрозаводск : Петразаводский гос. университет. 651 с. C. 5-30.

Зырянов, О. В. (2018) Введение в этнопоэтику русской классической литературы : учебное пособие. М. : Флинта ; Екатеринбург : Изд-во Урал. ун-та. 216 с.

История тувинской литературы (2013) : в 2 т. / отв. ред. К. А. Бичелдей. Новосибирск: Издательство СО РАН. Т. 1. 266 c.

Карамашева, В. А. (1995) В. Г. Майнашев // Майнашев В. Г. Крашеные ковыли: стихи и поэмы. Абакан : Хакасское книжное изд-во. 112 с. С. 5-7.

Караулов, Ю. Н. (1987) Русский язык и языковая личность / отв. ред. Д. Н. Шмелев. М. : Наука. 261 с.

Котожеков, Г. Г. (1995) Культура народов Саяно-Алтая. Абакан : Хакасское книжное издательство. 208 с.

Кошелева, А. Л. (2015) Проблемы билингвизма в транскультурной (транснациональной) литературе: национально-художественное своеобразие русскоязычных хакасских писателей (XX в. - нач. XXI в.). Абакан : Хакасское книжное издательство. 270 с.

Куулар, Д. С. (2002) История и современность. Кызыл : Тувинское книжное издательство. 144 с.

Кудияров, А. В. (2002) Художественно-стилевые традиции эпоса монголоязычных и тюркоязычных народов Сибири. М. : ИМЛИ РАН. 329 с.

Кызласов, Л. Р. (1969) Древние крепости Хакасии // Археологические открытия 1968 года / отв. ред. Б. А. Рыбаков. М. : Наука. 463 с. С. $244-246$.

Лагунова, О. К. (2008) Феномен творчества русскоязычных писателей-ненцев и хантов последней трети XX века (Е. Айпин, Ю. Вэлла, А. Неркаги) : автореф.... д-ра филол. наук. СПб. 42 с.

Ламажаа, Ч. К. (2013) Тувиноведение: новые горизонты. М. : Книжный дом «Либроком». 184 с.

Майнагашева, Н. С. (2008) Хакасская драматургия 1920-1990-х годов: поэтика, типология, закономерности развития. Абакан : Хакасское книжное издательство. 149 с.

Маслова, В. А. (2016) Поэтический текст: Новые подходы и решения: учебное пособие. М. : Флинта ; Наука. 320 с.

Мижит, Л. С. (2006) Лирические миниатюры в тувинской поэзии // Методологические проблемы изучения истории литератур народов Сибири : материалы региональной конференции / отв. ред. А. С. Донгак. Кызыл : Тувинский институт гум. исследований. 162 с. С. 103-108. 
Мижит, Л. С. (2013) Тувинское трехстишие. Триада в тувинской традиционной культуре. Новосибирск : Изд-во CO PAH. 138 c.

Миллер, Г. Ф. (1999) История Сибири. М.: Издательская фирма «Восточная литература» РАН. 630 с.

Орус-оол, С. М. (2001) Тувинские героические сказания: текстология, поэтика и стиль : автореф. дис. ... д-ра фил. наук. М. 47 с. 25 c.

Очур, Т. Х. (2008) Этнопоэтическое своеобразие прозы С. Сарыг-оола: автореф... канд. филол. наук. Улан-удэ.

Прищепа, В. П. (2006) Щемящей совести строка: Книга о современной литературе Хакасии. Новосибирск : Новосибирское книжное издательство. 336 с.

Самдан, 3. Б. (2010) Предпосылки к изучению фольклоризма тувинской литературы в постсоветское время // ЭТНО: литературоведение и литературное образование: перспективы и приоритеты: Материалы регион. науч. симпозиума с междунар. участием, посвящ. 75-лети. проф. С. Ж. Балданова : в 2 ч. / науч. ред. Б. Б. Бадмаев. УланУдэ: Издательство Бурятского госунивер-та. Ч. І. 290 с. С. 269-274.

Самдан, 3. Б. (2013) Устное народное творчество тувинцев- художественная основа тувинской литературы // История тувинской литературы : в 2 т. / отв. ред. К. А. Бичелдей. Новосибирск: Издательство СО РАН. Т. 1.266 с. C. $11-51$.

Султанов, К. К. (1996) «Лабиринт сцеплений». Этническое - национальное - художественное // История национальных литератур. Перечитывая и переосмысливая / отв. ред. Р. Ф. Юсуфов. М. : Наследие. Вып. 2.288 с. С. 150 -161.

Султанов, К. К. (2006) Идентичность и контекст. Этническое и художественное в литературах Северного Кавказа // Слово и мудрость Востока. Литература. Фольклор. Культура / отв. ред. Н. И. Никулин. М. : Наука. 582 с. С. 233-242.

Табакова, 3. П. (2014) Этнопоэтика. Диалог культур и языков. Saarbrucken : Palmarium Academic Publishing. 140 с.

Хадаханэ, М. А. (1986) Литературная Тува. Кызыл : Тувинское книжное издательство. 122 с.

Чаптыкова, Ю. И. (2013) Этнопоэтическое своеобразие прозы И. Костякова. Абакан : Хакасское книжное издательство. 148 с.

Челтыгмашева, Л. В. (2009) Этнопоэтическое своеобразие хакасской прозы 1930-1990-х гг. : автореф. ... канд. филол. наук. Улан-Удэ. 19 с.

Чернова, А. Е. (2013) Этнопоэтические константы образа Русской земли в лирике Н. Рубцова // Philologia nova. Лингвистика и литературоведение : сборник статей молодых исследователей / редкол.: М. В. Сандакова, Д. Н. Черниговский, О. В. Редькина. Киров : Изд-во ВятГГУ. 172 с. С. 164-169.

Чендекова, А. Б. (2017) Мифопоэтические образы в лирике некоторых тюркоязычных поэтов // Актуальные вопросы алтайского языкознания: проблемы развития литературного языка, совершенствование современной орфографии / А. Э. Чумакаев (отв. ред.). Горно-Алтайск: Горно-Алтайская типография. 336 с. С. 203-206.

Rotenberg, G. D. (1983) Symposium of the Whole: A Range of Discourse Toward An Ethnopoetics. California : University of California press. $503 \mathrm{p}$.

Jason, H. (2000) Motif, type and genre: A manual for compilation of indixes \& a bibliography of indices and indixing. Helsinki : Suomal. Tiedeakat. 279 p.

Дата поступления: 21.03.2020 г.

\section{REFERENCES}

Alefirenko, N. F., Golovaneva, M. A., Ozerova, E. G. and Chumak-Zhun', I. I. (2012) Tekst i diskurs [Text and discourse]: a textbook for undergraduates. Moscow, Flinta, Nauka. 232 p. (In Russ.).

Antoshin, K. F. (1982) U istokov zhizni: o sovremennoi literature Khakasii, Tuvy, Gornogo Altaia, Krasnoiarskogo kraia [At the origins of life: on the modern literature of Khakassia, Tuva, Gorny Altai, Krasnoyarsk Krai]. Krasnoiarsk, Krasnoyarsk book publishing house. 96 p. (In Russ.).

Bavuu-Surun, M. V., Shirobokova, N. N. and Samdan, A. M. (2018) Nazvaniia lekarstvennykh rastenii Tuvy v slovariakh [The Nomenclature of Medicinal Plants of Tuva in Dictionaries]. New Research of Tuva, no. 4, pp. 30-46. (In Russ.). DOI: https://doi.org/10.25178/nit.2018.4.2

Baldanov, S. Zh. (1983) Obshchnost' natsional'nykh literatur Sibiri [Commonality of national literatures of Siberia]. In: Vzaimodeistvie literatur narodov Sibiri [Interaction between literatures of the peoples of Siberia] / ed. by G. I. Lomidze. Novosibirsk, Nauka, Sibirskoe otdelenie. 272 p. Pp. 147-152. (In Russ.). 
Baldanov, S. Zh. (2005) Formula edinstva sibirskikh natsional'nykh literatur i formy mezhliteraturnykh kommunikatsii [Formula of unity of Siberian national literatures and forms of inter-literary communication]. In: Sibir' - edinoe fol'klorno-literaturnoe polietnicheskoe prostranstvo [Siberia is a unified multi-ethnic folklore and literary space]: in 2 parts / ed. by S. Zh. Baldanov. Ulan-Ude, GUP «ID» «Buriaad unen». Part I. Vol. I. 180 p. Pp. 5-9. (In Russ.).

Bikmukhametov, R. G. (1983) Orbity vzaimodeistviia [Orbits of interaction]. Moscow, Sovetskii pisatel'. 240 p. (In Russ.).

Butanaev, V. Ya., Vernik, A. A. and Ulturgashev, A. A. (1999) Narodnye prazdniki Khakasii [Folk holidays of the Republic of Khakassia] : a training manual. Abakan, KhSU Publ. 208 p. (In Russ.).

Galimova, E. Sh. (2015) K voprosu o metodologii issledovaniia lokal'nykh (gorodskikh i regional'nykh) literaturnykh tekstov (na primere Severnogo teksta russkoi literatury) [On the methodology of researching local (urban and regional) literary texts: the case of the Northern text of Russian literature]. In: Sibirskaia identichnost' v zerkale literaturnogo teksta: tropy, toposy, zhanrovye formy $X I X-X X v v$. [Siberian identity in the mirror of a literary text: tropes, topoi, genre forms in the XIX-XX centuries] / ed. by N. V. Kovtun. Moscow, Flinta, Nauka. 456 p. Pp. 380-395. (In Russ.).

Gatsak, V. M. (2000) Severnye etnopoeticheskie konstanty [Northern ethnopoetic constants]. In: Narodnaia kul'tura Russkogo Severa. Zhivaia traditsiia: Materialy respublikanskoi shkoly-seminara [Folk culture of the Russian North. Living tradition: Proceedings of the Republican school-seminar]. Vol. 2 / ed. by N. V. Drannikova and Yu. A. Novikov. Arkhangel'sk, Izd-vo Pomorskogo gosudarstvennogo universiteta. 136 p. Pp. 7-10. (In Russ.).

Dalgat, U. B. (2004) Etnopoetika v russkoi proze 20-90-kh gg. XX veka (Ekskursy) [Ethnopoetics in Russian prose of the 20-90s of the XX century (Excursions)]. Moscow, IMLI RAN. 212 p. (In Russ.).

Dongak, U. A. (2013) Predposylki zarozhdeniia tuvinskoi literatury [Prerequisites for the origin of Tuvan literature]. In: Istoriia tuvinskoi literatury [The history of Tuvan literature]: in 2 vol. / ed. by K. A. Bicheldei. Novosibirsk, Izdatel'stvo SO RAN. Vol. 1. 266 p. Pp. 103-108. (In Russ.).

Zakharov, V. N. (1998) Pravoslavnye aspekty etnopoetiki russkoi literatury [Orthodox aspects of ethnopoetics of Russian literature]. In: Evangel'skii tekst v russkoi literature XVIII-XX vekov [The gospel text in Russian literature of the XVIII-XX centuries] / ed. by V. N. Zakharov. Vol. 2. Petrozavodsk, Petrazavodskii gos. universitet. 651 p. Pp. 5-30. (In Russ.).

Zyrianov, O. V. (2018) Vvedenie v etnopoetiku russkoi klassicheskoi literatury [Introduction to the ethnopoetics of Russian classical literature]: textbook. Moscow, Flinta; Ekaterinburg, Izd-vo Ural. un-ta. 216 p. (In Russ.).

Istoriia tuvinskoi literatury [A History of Tuvan Literature] (2013). Novosibirsk, Nauka. Vol. 1. 264 p. (In Russ.).

Karamasheva, V. A. (1995) V. G. Mainashev. In: Mainashev V. G. Krashenye kovyli [Painted hobbles]: poems. Abakan, Khakas book publishing house. 112 p. Pp. 5-7. (In Russ.).

Karaulov, Yu. N. (1987) Russkii iazyk i iazykovaia lichnost' [Russian language and language personality] / ed. by D. N. Shmelev. Moscow, Nauka. 261 p. (In Russ.).

Kotozhekov, G. G. (1995) Kul'tura narodov Saiano-Altaia [Culture of the Sayano-Altai peoples]. Abakan, Khakas book publishing house. 208 p. (In Russ.).

Kosheleva, A. L. (2015) Problemy bilingvizma v transkul'turnoi (transnatsional'noi) literature: natsional'no-khudozhestvennoe svoeobrazie russkoiazychnykh khakasskikh pisatelei (XXv. - nach.XXIv.) [Problems of bilingualism in transcultural and transnational literature: ethnic and artistic originality of Russian-speaking Khakas writers: $20^{\text {th }}$ and early $21^{\text {st }}$ century]. Abakan, Khakas book publ. 270 p. (In Russ.).

Kuular, D. S. (2002) Istoriia i sovremennost' [History and modernity]. Kyzyl, Tuvan book publ. 144 p. (In Russ.).

Kudiiarov, A. V. (2002) Khudozhestvenno-stilevye traditsii eposa mongoloiazychnykh i tiurkoiazychnykh narodov Sibiri [Artistic and stylistic traditions of the epic of the Mongol-speaking and Turkic-speaking peoples of Siberia]. Moscow, IMLI RAN. 329 p. (In Russ.).

Kyzlasov, L. R. (1969) Drevnie kreposti Khakasii [Ancient fortresses of Khakassia]. In: Arkheologicheskie otkrytiia 1968 goda [Archaeological discoveries in 1968] / ed. by B. A. Rybakov. Moscow, Nauka. 463 p. Pp. 244-246. (In Russ.).

Lagunova, O. K. (2008) Fenomen tvorchestva russkoiazychnykh pisatelei-nentsev i khantov poslednei treti XX veka (E. Aipin, Iu. Vella, A. Nerkagi) [The phenomenon of Russian-language Nenets and Khanty writers of the last third of the 20 $0^{\text {th }}$ century: E. Aipin, Yu. Vella, A. Nerkagi]: Abstract of Diss.... Doctor of Philology. St. Petersburg. 42 p. (In Russ.).

Lamazhaa, Ch. K. (2013) Tuvinovedenie: novye gorizonty [Tuvan studies: new horizons]. Moscow, Librokom. 184 p. (In Russ.).

Mainagasheva, N. S. (2008) Khakasskaia dramaturgiia 1920-1990-kh godov: poetika, tipologiia, zakonomernosti razvitiia [Khakas drama of the 1920-1990s: poetics, typology, development patterns]. Abakan, Khakas book publ. 149 p. (In Russ.).

Maslova, V. A. (2016) Poeticheskii tekst: Novye podkhody i resheniia [Poetic text: New approaches and solutions]: a training manual. Moscow, Flinta; Nauka. 320 p. (In Russ.). 
Mizhit, L. S. (2006) Liricheskie miniatiury v tuvinskoi poezii [Lyrical miniatures in Tuvan poetry]. In: Metodologicheskie problemy izucheniia istorii literatur narodov Sibiri [Methodological problems of studying the history of literature of the peoples of Siberia]: Proceedings of a regional conference / ed. by A. S. Dongak. Kyzyl, Tuvinskii institut gum. issledovanii. 162 p. Pp. 103-108. (In Russ.).

Mizhit, L. S. (2013) Tuvinskoe trekhstishie. Triada v tuvinskoi traditsionnoi kul'ture [Tuva tercet: the Triad in Tuvan traditional culture]. Novosibirsk, SO RAN Publ. 138 p. (In Russ.).

Miller, G. F. (1999) Istoriia Sibiri [The history of Siberia]. Moscow, Vostochnaia literature Publ. 630 p. (In Russ.).

Orus-ool, S. M. (2001) Tuvinskie geroicheskie skazaniia: tekstologiia, poetika i stil' [Tuvan heroic legends: textual criticism, poetics and style] : Abstract of Diss. ... Doctor of Philology. Moscow. 47 p. (In Russ.).

Ochur, T. Kh. (2008) Etnopoeticheskoe svoeobrazie prozy S. Saryg-oola [Ethnopoetic originality of S. Saryg-ool's prose]: Abstract of Diss. ... Candidate of Philology. Ulan-Ude. 25 p. (In Russ.).

Prishchepa, V.P. (2006) Shchemiashchei sovesti stroka: Kniga o sovremennoi literature Khakasii [A line of aching conscience: A book on contemporary literature in the Republic of Khakassia]. Novosibirsk, Novosibirsk book publishing house. 336 p. (In Russ.).

Samdan, Z. B. (2010) Predposylki k izucheniiu fol'klorizma tuvinskoi literatury v postsovetskoe vremia [Prerequisites for the study of Tuvan literature folklore in the post-Soviet period]. In: ETNO: literaturovedenie i literaturnoe obrazovanie: perspektivy i prioritety [ETNO: literary studies and literary education: perspectives and priorities]: Proceedings of a regional symposium and international conference dedicated to 75th anniversary of Prof. S. Zh. Baldanov : in 2 parts / ed. by B. B. Badmaev. Ulan-Ude, Buryat State University publishing house. Part I. 290 p. Pp. 269-274. (In Russ.).

Samdan, Z. B. (2013) Ustnoe narodnoe tvorchestvo tuvintsev - khudozhestvennaia osnova tuvinskoi literatury [Oral folk art of Tuvans is the artistic basis of Tuvan literature]. In: Istoriia tuvinskoi literatury [A History of Tuvan Literature] (2013). Novosibirsk, Nauka. Vol. 1. 264 p. Pp. 11-51 (In Russ.).

Sultanov, K. K. (1996) «Labirint stseplenii». Etnicheskoe - natsional'noe - khudozhestvennoe ["The labyrinth of couplings". Ethnic - national - artistic]. In: Istoriia natsional'nykh literatur. Perechityvaia i pereosmyslivaia [History of national literatures. Rereading and rethinking] / ed. by R. F. Iusufov. Moscow, Nasledie. Vol. 2. 288 p. Pp. 150-161. (In Russ.).

Sultanov, K. K. (2006) Identichnost' i kontekst. Etnicheskoe i khudozhestvennoe v literaturakh Severnogo Kavkaza [Identity and context. Ethnic and artistic in the literatures of the North Caucasus]. In: Slovo i mudrost' Vostoka. Literatura. Fol'klor. Kul'tura [The word and wisdom of the East. Literature. Folklore. Culture] / ed. by N. I. Nikulin. Moscow, Nauka. 582 p. Pp. 233-242. (In Russ.).

Tabakova, Z. P. (2014) Etnopoetika. Dialog kul'tur i iazykov [Ethnopoetics. Dialogue of cultures and languages]. Saarbrucken, Palmarium Academic Publishing. 140 p. (In Russ.).

Khadakhane, M. A. (1986) Literaturnaia Tuva [The literary Tuva]. Kyzyl, Tuvan book publisher. 122 p. (In Russ.).

Chaptykova, Yu. I. (2013) Etnopoeticheskoe svoeobrazie prozy I. Kostiakova [Ethnopoetical originality of the prose of I. Kostyakov]. Abakan, Khakas book publishing house. 148 p. (In Russ.).

Cheltygmasheva, L. V. (2009) Etnopoeticheskoe svoeobrazie khakasskoi prozy 1930-1990-kh gg. [Ethnopoetical originality of Khakas prose of the 1930s - 1990s.] : Abstract of Diss. ... Candidate of Philology. Ulan-Ude. 19 p. (In Russ.).

Chernova, A. E. (2013) Etnopoeticheskie konstanty obraza Russkoi zemli v lirike N. Rubtsova [Ethnopoetical constants of the Russian land in N. Rubtsov's lyrics]. In: Philologia nova. Lingvistika i literaturovedenie [Philologia nova. Linguistics and literary studies]: a collection of articles by young researchers / editorial board M. V. Sandakova, D. N. Chernigovskii and O. V. Red'kina. Kirov, ViatGGU Publ. 172 p. Pp. 164-169. (In Russ.).

Chendekova, A. B. (2017) Mifopoeticheskie obrazy v lirike nekotorykh tiurkoiazychnykh poetov [Mythopoetic images in the lyrics of some Turkic-speaking poets]. In: Aktual'nye voprosy altaiskogo iazykoznaniia: problemy razvitiia literaturnogo iazyka, sovershenstvovanie sovremennoi orfografii [Topical issues of Altai linguistics: problems of literary language development, improvement of modern spelling] / A. E. Chumakaev (ed.). Gorno-Altaisk, Gorno-Altaiskaia tipografiia. 336 p. Pp. $203-206$. (In Russ.).

Rotenberg, G. D. (1983) Symposium of the Whole: A Range of Discourse Toward An Ethnopoetics. California, University of California press. 503 p.

Jason, H. (2000) Motif, type and genre: A manual for compilation of indixes \& a bibliography of indices and indixing. Helsinki, Suomal. Tiedeakat. 279 p.

Submission date: 21.03.2020. 